\title{
Microflora in the Gut of Japanese Coastal Crustacea
}

\author{
Haruo Sugita, ${ }^{{ }_{1}}$ Ryutaro Ueda, ${ }^{* 1}$ Leslie R. Berger, ${ }^{* 2}$ \\ and Yoshiaki Deguchi*t
}

(Accepted January 16, 1987)

\begin{abstract}
Bacterial populations in gut contents and gills of seven marine crustacea were investigated qualitatively and quantitatively using nine different agar media. Total viable counts of the gut contents ranged from $10^{5}$ to $10^{9}$ cells $\mathrm{g}^{-1}$ and, of the gills, from $10^{6}$ to $10^{7}$ cells $\mathrm{g}^{-1}$. Three types of anaerobes, the Gram-positive coccus, Gram-positive rod and Gram-negative rod, were detected in $16.3 \%, 9.3 \%$ and $2.3 \%$, respectively, of the crustacean samples examined. Although Pseudomonas and 6 of the 20 subgroups of the genus Vibrio were distributed widely among the crustacea, other bacterial components were also present in significant number in the selected crustacean species, individual specimens, or specimen tissues. Furthermore, cardinal growth temperatures of the bacterial isolates obtained in this study suggest the surrounding water temperature to be a major factor influencing apparent seasonal shifts in the gut microflora.
\end{abstract}

Aquatic animals always take a large number of bacteria into their gut from water, sediment and/or food, Most of these bacteria are temporary residents, frequently because of incompatible physical and chemical conditions, lethal interactions between bacteria, and/or immune responses in the gut of the host animals. ${ }^{12}$ Certain bacteria are present in the gut for a relatively long term and they form the gut microflora specific to the host animals.

Although much information has been recently obtained with respect to the microflora of aquatic vertebrates, including fish, frogs and turtles, some knowledge is also available about that of crustacea. ${ }^{1)}$ The gut microflora of copepoda Acartia tonsa, ${ }^{2)}$ amphipod Boeckosmus affinis, ${ }^{3)}$ antarctic krill Euphausia superba, ${ }^{4}$ scampi Nephrops norvegicus, ${ }^{3)}$ freshwater shrimp Palaemon paucidens, ${ }^{8)}$ Japanese prawn Penaeus japonicus, ${ }^{, 2}$ giant prawn Machrobrachium rosenbergii, $^{8)}$ blue crab Callinectes sapidus $\left.{ }^{\theta}\right)$ and Majidae crab Chionoecetes opilio ${ }^{10}$ has been studied. These reported all showed that the aerobic heterotrophs, including Vibrio, Pseudomonas and coryneforms, were predominant in the gut of crustacea. Recently, obligately anaerobic bacteria have been isolated as the dominant micro-organisms from the gut contents of aquatic vertebrates. ${ }^{11^{-1}}$ ) However, few publications have dealt with anaerobes in the gut of crustacea. In this paper we describe the results of qualitative and quantitative investigations of viable heterotrophic bacteria, including anaerobes, in the gut of coastal crustacea.

\section{Materials and Methods}

\section{Animals}

All animals examined were caught by gill nets in the period from October 1984 to August 1985 at Shimoda, Shizuoka Prefecture, Japan. Water temperature during the period of collection ranged from $13.8^{\circ} \mathrm{C}$ in March to $26.0^{\circ} \mathrm{C}$ in August. The animals included 5 specimens of Japanese spiny lobster Panulirus japonicus (45.5 to $54.6 \mathrm{~g}$ in body weight), and 6 species of coastal crabs, including 6 specimens of Atergatis floridus (8.0 to $27.8 \mathrm{~g}$ ), 5 of Schizophrys aspera (11.7 to $17.1 \mathrm{~g}), 4$ of Tiarinia cornigera ( 9.3 to $12.5 \mathrm{~g}$ ), 5 of Pachygrapsus crassipes (5.6 to $16.3 \mathrm{~g}$ ), 5 of Thalamita prymna $(29.0$ to $56.0 \mathrm{~g})$ and 8 of Plagusia dentipes $(23.5$ to $40.2 \mathrm{~g}$ ).

\section{Media}

Nine different agar media were used:

PYBG, 1/20PYBG, N-PYBG and modified PEA[MPEA] agar media were already reported. ${ }^{18)}$ TCBS and BTB-Teepol agar media were commercially supplied from Eiken Co. (Tokyo).

MAGPC medium, ${ }^{17)}$ a selective medium for

\footnotetext{
*1 Department of Fisheries, Nihon University, Shimouma, Setagaya, Tokyo 154, Japan (杉田治男, 上田龍太 郎, 出口吉眧: 日本大学農缺医学部水座学科).

*2 Department of Microbiology, University of Hawaii, Honolulu, Hawaii, 96822, USA.
} 
marine anaerobic Gram-positive cocci, containing (in $\mathrm{g}$ per $1000 \mathrm{ml}$ of distilled water): Proteose peptone No. 3 (Difco), 10; Trypticase peptone (BBL), 3; Phytone peptone (BBL), 3; Lab-lemco powder (Oxoid), 2.4; liver extract (Kyokuto), 5; Bacto-yeast extract (Difco), 5; soluble starch, 0.5; glucose, $10 ; \mathrm{K}_{2} \mathrm{HPO}_{4}, 1 ; \mathrm{KH}_{2} \mathrm{PO}_{4}, 1 ; \mathrm{MgSO}_{4}$. $7 \mathrm{H}_{2} \mathrm{O}, 0.2 ; \mathrm{NaCl}, 15 ; \mathrm{MnSO}_{4}, 0.007$; L-cysteine hydrochloride, $0.5 ; \mathrm{FeSO}_{4} \cdot 7 \mathrm{H}_{2} \mathrm{O}, 0.2 ;$ Polysorbate 80,$1 ; \beta$-phenylethyl alcohol, 3; Bacto-agar, 15; adjusted to $\mathrm{pH}$ 7.2.

Modified DHL[MDHL] medium, which is Desoxycholate medium (Eiken) supplemented with $2 \%(\mathrm{w} / \mathrm{v}) \mathrm{NaCl}$.

Modified FM-CW[MFM-CW] medium, which is FM-CW medium (Eiken) supplemented with $5 \%$ $(\mathrm{v} / \mathrm{v})$ horse blood and $1.5 \%(\mathrm{w} / \mathrm{v})$ of $\mathrm{NaCl}$.

\section{Bacteriological Sampling}

Gut contents and gills were aseptically removed, liquified, quantitatively diluted with the seawater diluent and then inoculated onto the nine different aga media described above. The PYBG, 1/20 PYBG, TCBS, BTB, MDHL, and MPEA agars were incubated aerobically and the PYBG, NPYBG, MFM-CW, MPEA and MAGPC agars were incubated anaerobically, at $20^{\circ} \mathrm{C}$ for 12 to 14 days. Anaerobiosis was established in the anaerobic jar using GasPak anaerobic system (BBL).

After incubation, the bacterial colonies were divided into types according to colonial characteristics, that is, shape, size, elevation, structure, surface, edge, color and opacity, and the number of colonies of each recognizable type was counted in all the agar media. Three representatives of each colony type were streaked onto PYBG or $1 / 20$ PYBG agars, and purified by a second plating into the same medium.

\section{Identification of Bacteria}

The bacteria isolated aerobically, were identified to genera according to a modification ${ }^{18)}$ of the scheme of Shewan et al., ${ }^{18}$ ) and the manuals of Cowan $^{18)}$ and Krieg and Holt. ${ }^{20)}$ Vibrionaceae were further classified by the ability to form pigment and swarm on PYBG agar; to grow at $37^{\circ} \mathrm{C}$; produce indole and acetylmethylcarbinol (VP reaction); reduce nitrate; produce any acid from sucrose, arabinose and inositol; and react on TCBS agar. Obligate and facultative anaerobes isolated under anaerobic conditions were classified on the basis of Gram reaction, cellular morphology, spore formation and the ability to grow aerobically.

In suitable dilutions of each of the culture plates, the number of colonies of each bacterial group was counted and calculated into a count per $1 \mathrm{~g}$ of gut or gill material (wet weight). The maximum count for each bacterial group among the nine media was regarded as an accurate viable counts of the corresponding bacterial group. Total viable count (TVC) in each sample was obtained by summation of the viable counts of each bacterial group.

\section{Growth Response of Aerobic Isolates at Various Temperatures}

The bacterial strains isolated aerobically from Plagusia and Atergatis crabs were inoculated onto PYBG agars and incubated aerobically at various temperatures as follows: 5 and $10^{\circ} \mathrm{C}, 20$ days; 20,25 and $30^{\circ} \mathrm{C}, 7$ days; 37 and $42^{\circ} \mathrm{C}, 2$ days.

\section{Results}

\section{Colony Counts of Bacteria}

The number of colonies that formed on each type of agar medium varied from one sample to the next as follow: PYBG, $10^{5}$ to $10^{8}$ cells $\mathrm{g}^{-1}$ under both aerobic and anaerobic conditions; $1 / 20$ PYBG, $10^{8}$ to $10^{8}$ cells $\mathrm{g}^{-1}$; TCBS, $10^{4}$ to $10^{8}$ cells $\mathrm{g}^{-1}$; BTB, $10^{4}$ to $10^{8}$ cells $\mathrm{g}^{-1}$; MDHL, $10^{4}$ to $10^{8}$ cells $\mathrm{g}^{-1}$; MPEA, $10^{5}$ to $10^{8}$ cells $\mathrm{g}^{-1}$ under aerobic conditions, $10^{4}$ to $10^{7}$ cells $\mathrm{g}^{-1}$ under anaerobic conditions; N-PYBG, $10^{4}$ to $10^{8}$ cells $\mathrm{g}^{-1}$; MFM-CW, $<2 \times 10^{2}$ to $10^{7}$ cells $\mathrm{g}^{-1}$; MAGPC, $10^{4}$ to $10^{7}$ cells $\mathrm{g}^{-1}$.

\section{Bacteria Isolated}

A total of 1564 strains of aerobic and facultatively anaerobic bacteria was isolated aerobically. These were composed of Vibrionaceae (1363 strains), Pseudomonas (84), Micrococcus (44), Flavobacterium (38), Staphylococcus (29), coryneforms (4), Enterobacteriaceae (1) and Bacillus (1). The Vibrionaceae were further divided into 20 groups on the basis of 11 characteristics, as shown in Table 1. Their occurrence (number of strains isolated) in each of the crustacean species examined is also shown in Table 1.

A total of 1024 strains of anaerobic bacteria were isolated anaerobically. These were obligate anaerobes (51 strains) and facultative anaerobes (973). The obligate anaerobes consisted of Grampositive cocci (29), Gram-negative asporogenous rods (21) and a Gram-positive asporogenous rod (1). 
Table 1. Grouping of the bacteria belonging to genus Vibrio isolated from coastal crustacea

\begin{tabular}{|c|c|c|c|c|c|c|c|c|c|c|c|c|c|c|c|c|c|c|c|c|}
\hline \multirow{2}{*}{ Character } & \multicolumn{20}{|c|}{ Group } \\
\hline & 1 & 2 & 3 & 4 & 5 & 6 & 7 & 8 & 9 & 10 & 11 & 12 & 13 & 14 & 15 & 16 & 17 & 18 & 19 & 20 \\
\hline Sensitivity to $0 / 129$ & + & + & + & + & + & + & + & + & + & + & + & + & + & + & + & + & + & + & + & + \\
\hline Pigmentation & - & - & - & - & - & - & - & - & - & - & - & - & - & - & - & - & - & - & - & - \\
\hline Swarming & + & + & + & - & - & - & - & - & - & - & - & - & - & - & - & - & - & - & - & - \\
\hline Growth at $37^{\circ} \mathrm{C}$ & + & + & + & + & + & + & + & + & + & + & + & + & - & - & - & - & - & - & - & - \\
\hline Indole production & + & + & + & + & + & + & - & - & - & - & - & - & + & + & + & + & - & - & - & - \\
\hline Colony on TCBS $* 1$ & $\mathrm{Y}$ & $\mathbf{G}$ & $\mathrm{G}$ & $Y$ & $\mathbf{G}$ & - & $\mathbf{Y}$ & $\mathbf{Y}$ & $G$ & $\mathbf{B}$ & - & - & $\mathbf{Y}$ & G & G & W & $\mathbf{Y}$ & $\mathbf{G}$ & - & - \\
\hline \multicolumn{21}{|l|}{ Acid from: } \\
\hline Sucrose & + & - & - & + & - & - & + & + & - & - & - & - & + & - & - & - & + & - & + & - \\
\hline Arabinose & - & + & - & - & - & - & + & - & - & - & - & - & - & + & - & - & - & - & - & - \\
\hline Inositol & - & - & - & - & - & - & - & - & - & - & - & - & - & - & - & - & - & - & - & - \\
\hline VP reaction & + & + & + & - & - & - & - & - & - & - & - & - & - & - & - & - & - & - & - & - \\
\hline Nitrate reduction & + & + & + & + & + & + & + & + & + & + & - & + & + & + & + & + & + & + & + & - \\
\hline \multicolumn{21}{|l|}{ Crustacean species } \\
\hline Japanese spiny lobster & $69 * 2$ & 0 & 0 & 75 & 200 & 2 & $\mathbf{0}$ & 7 & 12 & 3 & 0 & $\mathbf{0}$ & 55 & 0 & 42 & 0 & 3 & 14 & 7 & 0 \\
\hline Atergatis crab & 0 & 0 & 0 & 2 & 9 & $\mathbf{0}$ & 0 & 0 & 2 & 0 & 0 & 0 & 42 & 0 & 70 & 0 & 3 & 14 & 9 & 0 \\
\hline Schizophrys crab & 0 & 0 & 0 & 2 & 18 & 0 & 0 & 0 & 7 & 0 & 1 & 0 & 10 & 0 & 68 & 3 & 1 & 1 & 0 & 3 \\
\hline Tiarinia crab & 0 & 0 & 0 & 1 & 15 & 0 & 0 & 0 & 7 & 0 & 1 & 0 & 28 & 2 & 50 & 0 & 1 & 11 & 0 & 1 \\
\hline Pachygrapsus crab & 0 & 0 & 0 & 27 & 5 & 1 & 0 & 0 & 2 & 0 & 0 & 4 & 21 & 0 & 12 & 0 & 0 & 5 & 0 & 0 \\
\hline Thalamita crab & 9 & 2 & 2 & 69 & 2 & 10 & 0 & 0 & 8 & 0 & 2 & 0 & 27 & 0 & $\mathbf{0}$ & 0 & 0 & 0 & 0 & 0 \\
\hline Plagusia crab & 38 & 0 & 0 & 38 & 11 & 0 & 3 & 4 & 3 & 0 & 0 & 0 & 99 & 0 & 84 & 0 & 0 & 4 & 0 & 0 \\
\hline Total & 116 & 2 & 2 & 214 & 260 & 13 & 3 & 11 & 41 & 3 & 4 & 4 & 282 & 2 & 326 & 3 & 8 & 49 & 16 & 4 \\
\hline
\end{tabular}

*1 Y, yellow; G, green; B, brown; W, white; -, no growth.

*2 Number of strains. 
Table 2. Specific viable counts of bacteria in the gills and guts of Japanese spiny lobster

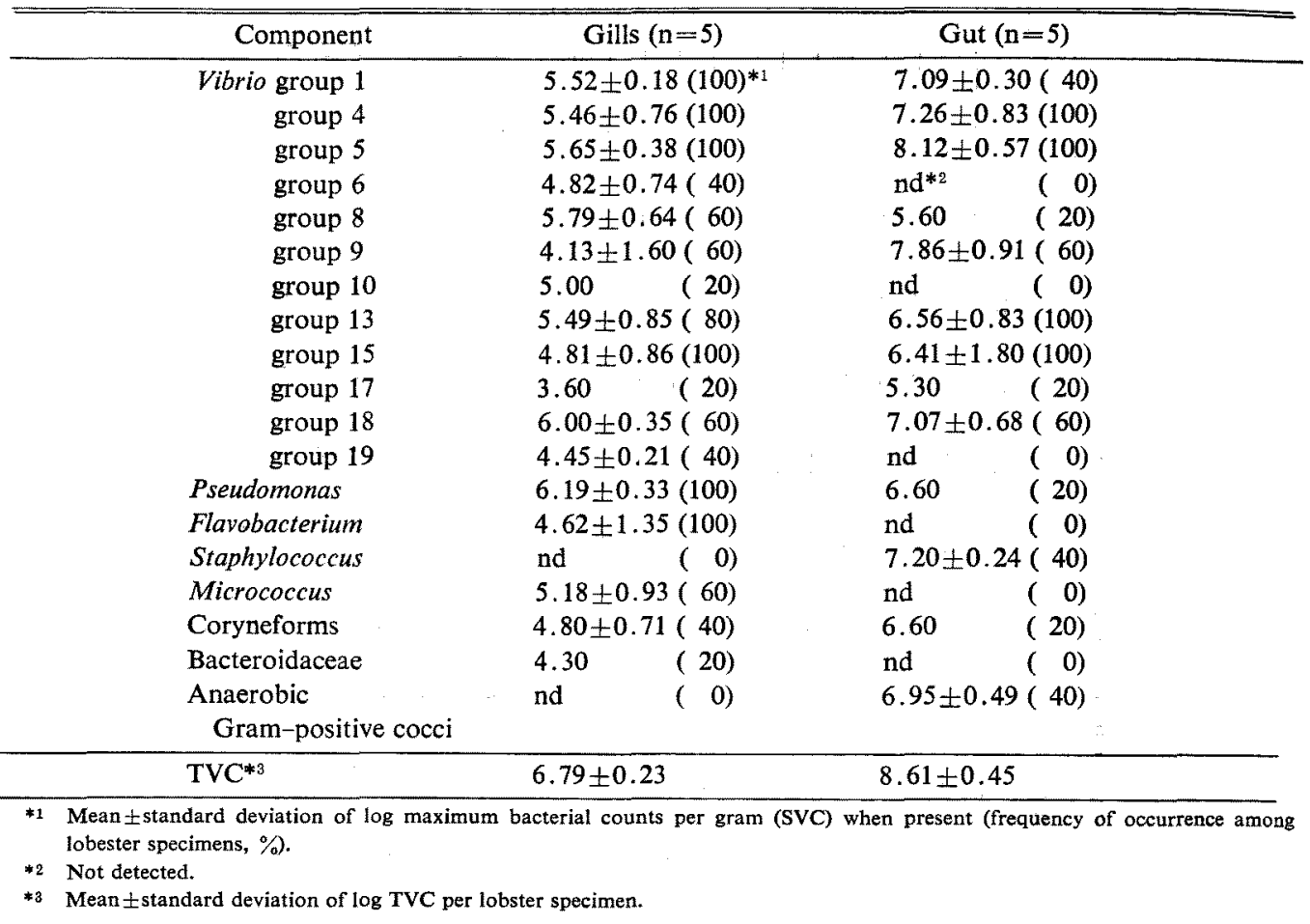

Microflora of Gills and Gut Contents of Coastal Crustacea

Viable counts of various groups of bacteria and TVCs in the gills and gut contents of the specimens of Japanese spiny lobster are given in Table 2. The lobsers were collected in October at which time water temperature was $20.8^{\circ} \mathrm{C}$.

In the gills of the lobster, TVCs ranged from $10^{8}$ to $10^{7}$ cells $\mathrm{g}^{-1}$, and 17 bacterial components were isolated. Vibrio were divided into 12 groups. Vibrio groups 1, 4, 5 and 15, Pseudomonas and Flavobacterium were isolated from all five lobsters at bacterial densities of $10^{2}$ to $10^{6}$ cells $\mathrm{g}^{-1}$. Anaerobes (Bacteroidaceae) were isolated from one of the 5 specimens.

In the guts of the lobsters described above, TVCs ranged from $10^{7}$ to $10^{9}$ cells $\mathrm{g}^{-1}$, and 13 bacterial components were detected. Of 9 groups of Vibrio isolated, groups 4, 5, 13 and 15 were ubiquitous to all specimens with bacterial densities of $10^{3}$ to $10^{8}$ cells $\mathrm{g}^{-1}$. Anaerobes (Gram-positive cocci) were isolated from two individuals at bacterial densities of $10^{8}$ to $10^{8}$ cells $\mathrm{g}^{-1}$.

Gut microflora of 6 coastal crabs is summarized in Table 3. TVCs ranged from $10^{5}$ to $10^{\theta}$ cells $\mathrm{g}^{-1}$.

From Atergatis crabs collected in March at $13.8^{\circ} \mathrm{C}, 13$ bacterial components were isolated. Of the 5 Vibrio groups detected, only group 18 occurred in all samples. In the crab samples collected in April at $17.0^{\circ} \mathrm{C}, 10$ bacterial components were detected. Of five groups of Vibrio isolated, groups 5,13 and 15 occurred in all three individuals. The bacterial components isolated from 2 of the 3 specimens were Vibrio group 4, Pseudomonas and Staphylococcus. Anaerobes (Gram-positive cocci) were detected in only one crab collected in April.

From Schizophrys crabs collected in April at $17.0^{\circ} \mathrm{C}, 15$ bacterial components were isolated, 10 of which were Vibrio groups. Only Vibrio group 15 was common to all five crab specimens. Vibrio group 13 and Pseudomonas each occurred in 4 of the 5 specimens. No anaerobes were detected in this type of crab.

In Tiarinia crabs collected in April at $17.0^{\circ} \mathrm{C}$, 14 bacterial components containing 10 groups of Vibrio were detected. Vibrio groups 13 and 15 each occurred in all four crabs with bacterial densities of $10^{5}$ to $10^{7}$ cells $\mathrm{g}^{-1}$. Anaerobes (Gram-positive cocci) were isolated from two crab samples.

From Pachygrapsus crabs collected in June at $21.7^{\circ} \mathrm{C}, 14$ bacterial components were isolated, 


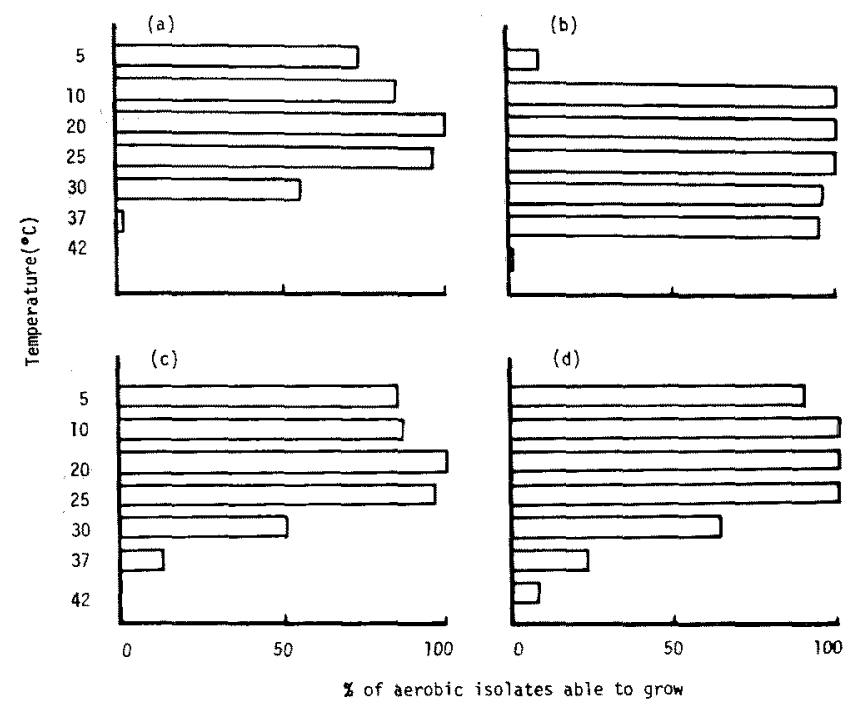

Fig. 1. Growth temperature spectra of the isolates from the gut contents of Plagusia and Atergatis crabs. a, Plagusia crabs caught in March $\left(13.8^{\circ} \mathrm{C}\right)$; b, in August $\left(26.0^{\circ} \mathrm{C}\right) ; \mathrm{c}$, Atergatis in March $\left(13.8^{\circ} \mathrm{C}\right) ; \mathrm{d}$, in April $\left(17.0^{\circ} \mathrm{C}\right)$.

including 8 groups of Vibrio. Vibrio groups 4 , 5, 13 and 18, Flavobacterium, Micrococcus and anaerobic asporogenous Gram-positive rods were detected in 60 to $80 \%$ of the specimens examined. In addition to the anaerobic rod, Gram-positive cocci were isolated from two crabs as anaerobic components.

In Thalamita crabs collected in August at $26.0^{\circ} \mathrm{C}$, 13 bacterial components containing 9 groups of Vibrio were detected. Only Vibrio group 4 were common to all five crabs. No anaerobes were isolated from these animals.

From the Plagusia crabs collected in March at $13.8^{\circ} \mathrm{C}, 6$ bacterial groups were isolated. Vibrio consisted of 3 groups, of which only group 13 was present in all five crabs. In the crabs collected in August at $26.0^{\circ} \mathrm{C}, 9$ bacterial components containing 7 groups of Vibrio were detected. Vibrio groups 1, 4 and 5 were present in all three crabs. No anaerobes were isolated from Plagusia crabs in either March or August.

Fig. 1 shows the growth spectra of the aerobic bacteria from Plagusia and Atergatis crabs at temperatures ranging from 5 to $42^{\circ} \mathrm{C}$. The isolates from Plagusia crabs collected in March (water temperature of $13.8^{\circ} \mathrm{C}$ ) could not grow at $37^{\circ} \mathrm{C}$ but about $70 \%$ of the isolates grew at $5^{\circ} \mathrm{C}$. However, almost all strains isolated from the crab in August (water temperature of $26.0^{\circ} \mathrm{C}$ ) could grow at $37^{\circ} \mathrm{C}$ but not at $5^{\circ} \mathrm{C}$. These results suggested that differences in taxonomic composition of the gut microflora of this crab between March and August may be related to shifts in the ambient water temperature. A similar, though less marked, shift in temperature growth responses was detected for isolates from Atergatis crabs collected in March versus April, during which time a similar, though less marked, shift in ambient water temperature (from 13.8 to $17.0^{\circ} \mathrm{C}$ ) also occurred.

\section{Discussion}

In the present study, three types of anaerobic bacteria, the Gram-positive coccus, Gram-positive asporogenous rod and Gram-negative asporogenous rod, were isolated from coastal crustacea. Although various types of anaerobes have been known to exist in the gastrointestinal tract of freshwater vertebrates, including fishes, ${ }^{11,12,13}$ ) frogs $s^{14},{ }^{21)}$ and soft-shelled turtles, ${ }^{13)}$ there is little information on the anaerobes associated with maine animals. Shewan ${ }^{22}$ isolated anaerobic sporeforming bacteria from haddock Gadus aeglefinus and the authors ${ }^{163}, 23$ ) reported the presence of clostridia and Bacteroidaceae in coastal bivalves and fishes. Additionally, Dyrset et al. ${ }^{24)}$ isolated Bacteroidaceae from capelin Mallotus villosus. However, the isolation of anaerobic bacteria from marine crustacea has not been reported. This paper is the first demonstration that crustacea can have obligate anaerobes in their guts and gills. When detected, these 
Table 3. Specific viable counts of different components of bacteria in the gut contents of six coastal crabs

\begin{tabular}{|c|c|c|c|c|c|c|c|c|}
\hline \multirow{2}{*}{$\begin{array}{l}\text { Component } \\
\text { Vibrio group } 1\end{array}$} & \multicolumn{2}{|c|}{$\begin{array}{l}\text { Atergatis (Mar.) } \\
(\mathrm{n}=3)\end{array}$} & \multicolumn{2}{|c|}{$\begin{array}{l}\text { Atergatis (Apr.) } \\
(\mathrm{n}=3)\end{array}$} & \multicolumn{2}{|c|}{$\begin{array}{c}\text { Schizophrys } \\
(\mathrm{n}=5)\end{array}$} & \multicolumn{2}{|c|}{$\begin{array}{l}\text { Tiarinia } \\
(\mathrm{n}=4)\end{array}$} \\
\hline & $\mathrm{nd}^{* 1}$ & $(0)^{* 2}$ & nd & $(0)$ & nd & $(0)$ & nd & ( 0$)$ \\
\hline group 2 & nd & $(0)$ & nd & $(0)$ & nd & $(0)$ & nd & ( 0$)$ \\
\hline group 3 & nd & $(0)$ & nd & $(0)$ & nd & $(0)$ & nd & $(0)$ \\
\hline group 4 & nd & ( 0$)$ & \multicolumn{2}{|c|}{$6.37 \pm 0.59(67)$} & \multicolumn{2}{|c|}{$5.54 \pm 0.24(40)$} & 6.60 & ( 25$)$ \\
\hline group 5 & nd & $(0)$ & \multicolumn{2}{|c|}{$6.24 \pm 0.69(100)$} & 7.58 & $(20)$ & 7.33 & ( 25) \\
\hline group 6 & nd & $(0)$ & nd & $(0)$ & nd & $(0)$ & nd & $(0)$ \\
\hline group 7 & nd & $(0)$ & nd & $(0)$ & nd & $(0)$ & nd & $(0)$ \\
\hline group 8 & nd & $(0)$ & nd & $(0)$ & nd & $(0)$ & nd & $(0)$ \\
\hline group 9 & nd & $(0)$ & 6.25 & ( 33$)$ & 6.60 & (20) & 5.30 & (25) \\
\hline group 11 & nd & $(0)$ & nd & $(0)$ & 6.26 & $(20)$ & 5.30 & ( 25$)$ \\
\hline group 12 & & $(0)$ & & $(0)$ & nd & $(0)$ & nd & $(0)$ \\
\hline group 13 & \multicolumn{2}{|c|}{$6.60 \pm 1.84(67)$} & \multicolumn{2}{|c|}{$7.20 \pm 0.42(100)$} & \multicolumn{2}{|c|}{$6.04 \pm 0.62(80)$} & \multicolumn{2}{|c|}{$6.50 \pm 0.83(100)$} \\
\hline group 14 & nd & $(0)$ & nd & $(0)$ & nd & $(0)$ & 5.60 & ( 25$)$ \\
\hline group 15 & \multicolumn{2}{|c|}{$8.02 \pm 0.56(67)$} & \multicolumn{2}{|c|}{$7.15 \pm 0.60(100)$} & \multicolumn{2}{|c|}{$7.05 \pm 1.01(100)$} & \multicolumn{2}{|c|}{$6.96 \pm 0.60(100)$} \\
\hline group 16 & nd & $(0)$ & nd & $(0)$ & 6.41 & $(20)$ & nd & $(0)$ \\
\hline group 17 & \multicolumn{2}{|c|}{$8.25 \pm 0.23(67)$} & nd & $(0)$ & 6.08 & $(20)$ & 6.90 & ( 25) \\
\hline group 18 & \multicolumn{2}{|c|}{$6.95 \pm 1.55(100)$} & nd & $(0)$ & 6.60 & $(20)$ & \multicolumn{2}{|c|}{$6.71 \pm 0.37(50)$} \\
\hline group 19 & 6.30 & $(33)$ & nd & $(0)$ & nd & $(0)$ & nd & $(0)$ \\
\hline group 20 & nd & $(0)$ & nd & $(0)$ & 5.78 & $(20)$ & 5.30 & (25) \\
\hline Pseudomonas & \multicolumn{2}{|c|}{$5.95 \pm 0.92(67)$} & \multicolumn{2}{|c|}{$6.60 \pm 0.30(67)$} & \multicolumn{2}{|c|}{$6.77 \pm 0.40(80)$} & \multicolumn{2}{|c|}{$6.10 \pm 0.20(50)$} \\
\hline Flavobacterium & nd & $(0)$ & nd & $(0)$ & 6.30 & $(20)$ & nd & $(0)$ \\
\hline Enterobacteriaceae & nd & $(0)$ & nd & $(0)$ & 5.30 & $(20)$ & nd & $(0)$ \\
\hline Staphylococcus & 7.01 & ( 33$)$ & \multicolumn{2}{|c|}{$5.69 \pm 0.09(67)$} & \multirow{2}{*}{\multicolumn{2}{|c|}{$5.60 \pm 0.30(40)$}} & 5.30 & ( 25) \\
\hline Micrococcus & nd & $(0)$ & 6.30 & ( 33$)$ & & & \multicolumn{2}{|c|}{$5.80 \pm 0.50(50)$} \\
\hline Coryneforms & nd & $(0)$ & nd & $(0)$ & nd & $(0)$ & nd & $(0)$ \\
\hline Bacillus & nd & $(0)$ & 4.34 & ( 33) & 7.30 & ( 20$)$ & nd & ( 0$)$ \\
\hline $\begin{array}{l}\text { Anaerobic Gram- } \\
\text { positive rods }\end{array}$ & nd & $(0)$ & nd & $(0)$ & nd & $(0)$ & nd & $(0)$ \\
\hline $\begin{array}{l}\text { Anaerobic Gram- } \\
\text { positive cocci }\end{array}$ & nd & $(0)$ & 4.83 & ( 33$)$ & nd & $(0)$ & $5.56=$ & $(50)$ \\
\hline $\mathrm{TVC}^{* 3}$ & \multicolumn{2}{|c|}{$7.91 \pm 1.25$} & \multicolumn{2}{|c|}{$7.77 \pm 0.04$} & \multicolumn{2}{|c|}{$7.64 \pm 0.75$} & $7.54 \pm$ & \\
\hline
\end{tabular}

anaerobes were present at bacterial densities up to $10^{7}$ cells $\mathrm{g}^{-1}$. It is possible that their occurrence is restricted to certain species of crustacea, since anaerobes were never isolated from Schizophrys, Thalamita or Plagusia crabs, in the latter case regardless of water temperature. The low frequency of isolation of these bacteria may imply that they are transient forms in coastal crustacea. At present, these problems remain unresolved.

Nevertheless, the presence of these anaerobes is of much interest, because the information on the isolation of anaerobes (except for clostridia and Bacteroidaceae) from marine environments has been scarce. A detailed study concerning taxonomy and ecology of these organisms is now in progress.

The Japanese spiny lobster and Plagusia crab guts appear to support significantly higher bacterial populations than the other crab guts or the lobster gills. Similarly high TVCs of gut contents were also observed in fishes. ${ }^{15.23}$ ) The difference of TVCs of crustacean guts could be due to diet, physiological condition and species of host animal, and time lapse of digestion. At present, however, it remains unclear which is the major factor.

It has been known that microflora in the gut of crustacea is mainly composed of Vibrio, Pseudomonas and coryneforms as described already. In the present study, Vibrio and Pseudomonas were isolated from seven different species of marine crustacea. The Vibrio strains were further divided into 20 groups on the basis of 11 additional characters. Sizemore et al.," Sochard et al. ${ }^{2)}$ and Atlas et al. ${ }^{3)}$ classified the Vibrio strains isolated from blue crab, copepoda or amphipoda, 
Table 3. (Continued)

\begin{tabular}{|c|c|c|c|c|c|}
\hline \multirow{3}{*}{ 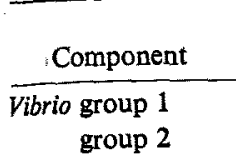 } & $\begin{array}{l}\text { Pachygrapsus } \\
(\mathrm{n}=5)\end{array}$ & \multirow{2}{*}{$\begin{array}{c}\begin{array}{c}\text { Thalamita } \\
(\mathrm{n}=5)\end{array} \\
5.92 \pm 0.23(60)\end{array}$} & $\begin{array}{c}\text { Plagusia (Mar.) } \\
(\mathrm{n}=5)\end{array}$ & \multirow{2}{*}{\multicolumn{2}{|c|}{$\frac{\begin{array}{c}\text { Plagusia (Aug.) } \\
(\mathrm{n}=3)\end{array}}{8.33 \pm 0.41(100)}$}} \\
\hline & $(0)$ & & $(0)$ & & \\
\hline & $(0)$ & $(20)$ & $(0)$ & nd & $(0)$ \\
\hline group 3 & $(0)$ & $(20)$ & $(0)$ & nd & $(0)$ \\
\hline group 4 & $6.32 \pm 1.21(80)$ & $6.91 \pm 0.62(100)$ & $(0)$ & $7.86=$ & $2(100)$ \\
\hline group 5 & $5.73 \pm 0.42(60)$ & $6.03 \pm 1.03(60)$ & $(0)$ & $6.97=$ & $7(100)$ \\
\hline group 6 & $(0)$ & $6.05 \pm 0.55(60)$ & $(0)$ & nd & $(0)$ \\
\hline group 7 & $(0)$ & $(0)$ & $(0)$ & 7.58 & (33) \\
\hline group 8 & $(0)$ & $(0)$ & $(0)$ & 7.30 & ( 33$)$ \\
\hline group 9 & $5.80 \pm 0.50(40)$ & $(20)$ & $(0)$ & 7.45 & (33) \\
\hline group 11 & $(0)$ & $5.95 \pm 0.58(40)$ & $(0)$ & nd & $(0)$ \\
\hline group 12 & $(20)$ & $(0)$ & $(0)$ & nd & $(0)$ \\
\hline group 13 & $6.19 \pm 0.25(60)$ & $6.58 \pm 0.60(80)$ & $7.70 \pm 1.48(100)$ & $7.25=$ & $5(67)$ \\
\hline group 14 & $(0)$ & nd $\quad(0)$ & nd $\quad(0)$ & nd & $(0)$ \\
\hline group 15 & $(20)$ & $(0)$ & $8.22 \pm 0.67(80)$ & nd & $(0)$ \\
\hline group 16 & $(0)$ & $(0)$ & nd $\quad(0)$ & nd & \\
\hline group 17 & $(0)$ & $(0)$ & $(0)$ & nd & $(0)$ \\
\hline group 18 & $6.20 \pm 0.70(60)$ & $(0)$ & $6.54 \pm 0.34(40)$ & nd & $(0)$ \\
\hline group 19 & $(20)$ & $(0)$ & $(0)$ & nd & $(0)$ \\
\hline group 20 & $(0)$ & $(0)$ & $(0)$ & nd & $(0)$ \\
\hline Pseudomonas & $6.70 \pm 0.40(40)$ & $5.63 \pm 0.41(80)$ & $6.87 \pm 0.51(60)$ & nd & $(0)$ \\
\hline Flavobacterium & $6.62 \pm 0.69(80)$ & $5.95 \pm 0.35(40)$ & $6.97 \pm 0.26(40)$ & nd & $(0)$ \\
\hline Enterobacteriaceae & $(0)$ & nd $\quad(0)$ & nd $\quad(0)$ & nd & $(0)$ \\
\hline Staphylococcus & $6.99 \pm 0.61(40)$ & $6.19 \pm 0.11(40)$ & $(0)$ & 7.60 & ( 33$)$ \\
\hline Micrococcus & $5.79 \pm 0.50(60)$ & $6.56 \pm 0.78(40)$ & $(0)$ & 8.38 & ( 33 ) \\
\hline Coryneforms & $(0)$ & $(0)$ & $(20)$ & nd & $(0)$ \\
\hline Bacillus & $(0)$ & $(0)$ & $(0)$ & nd & $(0)$ \\
\hline $\begin{array}{l}\text { Anaerobic Gram- } \\
\text { positive rods }\end{array}$ & $5.80 \pm 1.07(80)$ & $(0)$ & $(0)$ & nd & $(0)$ \\
\hline $\begin{array}{c}\text { Anaerobic Gram- } \\
\text { positive cocci }\end{array}$ & $6.32 \pm 0.95(40)$ & $(0)$ & $(0)$ & nd & $(0)$ \\
\hline TVC*3 & $7.65 \pm 0.43$ & $7.49 \pm 0.47$ & $8.45 \pm 0.64$ & 8.66 & \\
\hline
\end{tabular}

occurrence among crab specimens, $\%$. $* 3$ Mean \pm standard deviation of $\log$ TVC per crab specimen.

into various phena using numerical taxonomy. At present, it remains unresolved whether each group of Vibrio can be further classified into different species of Vibrio. In any case, it is clear from this study that the microflora of crustacea consists of many different bacterial components. One reason for the detection of this diversity may be the use of six different agar media for aerobic cultivation, because the effectiveness of isolating the bacteria varied with the medium used. Similar results were also obtained in a study of the bacterial populations in water, sediments and fish guts of freshwater environments. ${ }^{25)}$ These results suggest that the combination of non-selective and selective media allows a more complete investigation of the gut microflora of aquatic animals, as has already been shown for the homeothermal animals studied by Mitsuoka et al. ${ }^{28)}$

Tables 1 to 3 show that Vibrio groups 4, 5, 9, 13,
15 and 18, Pseudomonas, Staphylococcus, and Micrococcus are widely distributed in the crustacea. These bacterial components may be specific to coastal crustacea, but other bacteria were found in selected species, individual specimens, or specimen tissues.

A total of 17 components of bacteria was found in the gills of the Japanese spiny lobster while the microflora of their guts comprised 13 bacteria components, all of which were present in the gills. Liston $^{27)}$ reported that the diverse nature of the bacterial populations of skin and gills of fish is probably due to the ease of access of these sites of growth from the surrounding water and to the generally favorable conditions of growth provided by the slime secreted continuously from fish. Perhaps the diversity of gill microflora in crustacea is also affected by bacterial diversity in the surrounding water. With regards to the bacterial 
gut populations, some components may be inhibited by the characteristically low $\mathrm{pH}$, bile acids or anaerobic conditions in the gut, resulting in the dominace of certain Vibrio groups, as known in marine fish. ${ }^{28.28)}$

It was found from Table 3 that the gut microflora of Atergatis and Plagusia crabs varied significantly with sampling time. As shown in Fig. 1, the presence of isolates capable of growth at 5 and/or $37^{\circ} \mathrm{C}$ differed markedly between the Plagusia crabs collected in March at $13.8^{\circ} \mathrm{C}$ and in August at $26.0^{\circ} \mathrm{C}$. This result is perhaps a reflection of shift in surrounding water temperature. In the case of Atergatis crabs, the growth temperature spectra of their bacteria in March is similar to that of Plagusia bacteria in the same month, whereas the Atergatis bacteria in April at $17.0^{\circ} \mathrm{C}$ seem to be transient, or just beginning a shift from spring to summer composition. These results suggest that the gut microflora of coastal crustacea is easily influenced by the surrounding water temperature. In any case, the gut microflora of coastal crustacea might not be as stable as that observed in fishes. ${ }^{1)}$

It has been recently recognized that intestinal microflora of homeothermal animals play important roles in nutrition, carcinogenesis and self-defense of the host. ${ }^{30-32}$ Although it is believed that similar relationships occur in aquatic animals, there is a lack of evidence and only a few studies on this relationship have been reported. ${ }^{33-38)}$ Therefore, further studies of the gut microflora of crustacea concerning this problem should be performed.

\section{Acknowledgements}

This study was partly supported by Nihon University Ota Overseas Academic Intercharge Fund.

\section{References}

1) H. Sugita and Y. Deguchi: Aquabiol., 7, 242249 (1985).

2) M. R. Sochard, D. F. Wilson, B. Austin, and R. R. Colwell: Appl. Environ. Microbiol., 37, 750759 (1979).

3) R. M. Atlas, M. Busdosh, E. J. Krichevsky, and T. Kaneko: Can. J. Microbiol, 28, 92-99 (1982).

4) M.D. Kelly, S. Lukaschewsky, and C. G. Anderson: J. Food Sci., 43, 1196-1197 (1978).

5) D. C. Cann, G. O. Hobbs, B. R. Wilson, and R. W. Horsley: J. Food Technol., 6, 153-161
(1971).

6) H. Sugita, T. Takahashi, F. I. Kamemoto, and Y. Deguchi: Nippon Suisan Gakkaishi, 53, 511 (1987).

7) K. Yasuda and T. Kitao: Aquacult., 19, 229-234 (1980).

8) A. Colorni: Aquacult., 49, 1-10 (1985).

9) R. K. Sizemore, R. R. Colwell, H. S. Tubiash, and T. E. Lovelace: Appl. Environ. Microbiol., 29, 393-399 (1975).

10) K. Hayashi: in "Microbiological Aspects in Aquaculture" (ed. by A. Kawai), Koseisha Koseikaku, Tokyo, 1986, pp. 38-47.

11) T. J. Trust, L. M. Bull, B. R. Currie, and J.T. Buckley: J. Fish. Res. Board Can., 36, 11741179 (1979).

12) T. Sakata, H. Sugita, T. Mitsuoka, D. Kakimoto, and H. Kadota: Nippon Suisan Gakkaishi, 47, 421-427 (1981).

13) H. Sugita and Y. Deguchi: Nippon Suisan Gakkaishi, 49, 197-291 (1983).

14) H. Sugita, T. Nakajima, and Y. Deguchi: Nippon Suisan Gakkaishi, 51, 295-299 (1985).

15) H. Sugita, K. Tokuyama, and Y. Deguchi: Nippon Suisan Gakkaishi, 51, 1325-1329 (1985).

16) H. Sugita, H. Tanaami, T. Kobashi, and Y. Deguchi: Nippon Suisan Gakkaishi, 47, 655-661 (1981).

17) H. Sugita, R. Ueda, L. R. Berger, and Y. Deguchi: Food Microbiol., 3, 289-293 (1986).

18) J. M. Shewan, G. Hobbs, and W. Hodgkiss: $J$. appl. Bacteriol., 23, 379-390 (1960).

19) S. T. Cowan: Cowan and Steel's Manual for the Identification of Medical Bacteria, 2nd ed., Cambridge University Press, London, 1974, pp. 1-238.

20) N. R. Krieg and J. G. Holt (ed.): Bergey's Manual of Systematic Bacteriology, Vol. 1, Williams \& Wilkins, Baltimore, 1984, pp. 1-964.

21) J. Gossling, W. J. Loesche, and G. W. Nace: Appl. Environ. Microbiol., 44, 59-66 (1982).

22) J. M. Shewan: J. Bacteriol, 35, 397-407 (1938).

23) H. Sugita, T. Kobashi, A. Enomoto, K. Yamashita, and Y. Deguchi: Nippon Suisan Gakkaishi, 47, 557 (1981).

24) N. Dyrset, G. Bentzen, T. Arnesen, and H. Larsen: Arch. Microbiol., 139, 415-420 (1984).

25) H. Sugita and Y. Deguchi: Nippon Suisan Gakkaishi, 49, 1737-1740 (1983).

26) T. Mitsuoka, T. Sega, and S. Yamamoto: Z Zbl. f. Bakt. I. Org., 195, 69-79 (1964).

27) J. Liston: J. Gen. Microbiol., 16, 205-216 (1967).

28) H. Sera, Y. Ishida, and H. Kadota: in "Effect of the Ocean Environment on Microbial Activites" (ed. by R. R. Colwell and R. Y. Morita), University of Park Press, Baltimore, 1974, pp. 467-490.

29) K. Aiso, U. Simidu, and K. Hasuo: J. Gen. 
Microbiol., 52, 361-364 (1968).

30) T. Mitsuoka (ed.): Intestinal Flora and Carcinogenesis, Japan Sci. Soc. Press, Tokyo, 1981, pp. 1-183.

31) T. Mitsuoka (ed.): Intestinal Flora and Selfdefense, Japan Sci. Soc. Press, Tokyo, 1982, pp. 1-236.

32) T. Mitsuoka (ed.): Intestinal Flora and Nutrition. Japan. Sci. Soc. Press, Tokyo, 1983, pp. 1-211.
33) K. Kashiwada and S. Teshima: Nippon Suisan Gakkaishi, 32, 961-966 (1966).

34) T. D. Goodrich and R. Y. Morita: Mar. Biol., 41, 355-360 (1977).

35) T. Noguchi, J. K. Jeon, O. Arakawa, H. Sugita, Y. Deguchi, Y. Shida, and K. Hashimoto: $J$. Biochem., 99, 311-314 (1986).

36) T. Noguchi, D. F. Hwang, O. Arakawa, H. Sugita, Y. Deguchi, Y. Shida, and K. Hashimoto: Mar. Biol., 94, 625-630 (1987). 